Article (refereed)

Roy, Helen E.; Hails, Rosemary S.; Hesketh, Helen; Roy, David B.; Pell, Judith K.. 2009 Beyond biological control: non-pest insects and their pathogens in a changing world. Insect Conservation and Diversity, 2 (2). 65-72. 10.1111/j.1752-4598.2009.00046.x

(C) Royal Entomological Society

This version available at http://nora.nerc.ac.uk/5697/

NERC has developed NORA to enable users to access research outputs wholly or partially funded by NERC. Copyright and other rights for material on this site are retained by the authors and/or other rights owners. Users should read the terms and conditions of use of this material at http://nora.nerc.ac.uk/policies.html\#access

This document is the author's final manuscript version of the journal article, incorporating any revisions agreed during the peer review process. Some differences between this and the publisher's version remain. You are advised to consult the publisher's version if you wish to cite from this article.

http://www.blackwell-synergy.com 
Beyond biological control: non-pest insects and their pathogens in a changing world

Helen E. Roy ${ }^{1}$, Rosemary S. Hails ${ }^{2}$, Helen Hesketh ${ }^{2}$, David B. Roy ${ }^{1}$ and Judith. K. Pell ${ }^{3}$

${ }^{1}$ NERC Centre for Ecology and Hydrology - Wallingford, Maclean Building, Benson Lane, Crowmarsh Gifford, Oxfordshire, OX10 8BB, United Kingdom

${ }^{2}$ NERC Centre for Ecology and Hydrology - Oxford, Mansfield Road, Oxford, Oxfordshire, OX1 3SR, United Kingdom

${ }^{3}$ Department of Plant and Invertebrate Ecology, Rothamsted Research, Harpenden, Hertfordshire, AL5 2JQ, United Kingdom

Corresponding author: Helen E. Roy ${ }^{1}$ NERC Centre for Ecology and Hydrology - Wallingford, Maclean Building, Benson Lane, Crowmarsh Gifford, Oxfordshire, OX10 8BB, United Kingdom

e-mail:hele@ceh.ac.uk; T: 01491 692252; F: 01491692424

Running title: Insect conservation and disease

Keywords: Entomopathogen, environmental change, habitat fragmentation, non-pest insects, population dynamics, covert virus 
Over the last few decades there have been considerable advances in the fields of insect pathology and insect conservation but the two disciplines rarely meet. The potential of entomopathogens as biological control agents of pest insects is widely recognized but information on the role of pathogens in insect population regulation, more generally, is limited. For example, the role of pathogens as natural enemies of non-pest insects, including those of conservation value, is seldom considered beyond their context as 'non-targets' of microbial control agents. Entomopathogens are prevalent in natural systems and should receive greater attention in life history studies. There is no doubt that viruses, bacteria and fungi are major mortality agents of insects but their significance tends to be overshadowed by the attention given to predators and parasitoids. We highlight the critical function that entomopathogens could have in insect population dynamics with particular reference fragmented habitats as illustrated by the theoretical literature. However, we emphasize that there are few empirical studies to test theoretical predictions. Furthermore, we suggest that since an increase in the incidence of disease is predicted in most environmental change scenarios, it is more important than ever to turn our attention to insect pathology when we consider insect population dynamics.

The fields of insect pathology and insect conservation have made considerable advances over the last few decades, but the two disciplines rarely meet. The role of pathogens as natural enemies of insects (entomopathogens), including those of conservation value, is seldom considered (Roy and Cottrell, 2008). Naturally occurring entomopathogens are diverse and widespread (Lacey et al., 2001); $50 \%$ of living organisms are microbial (Watson et al., 1995) and insect pathogens are ubiquitous in both above and below-ground ecosystems (Hajek, 2004). However, most studies on insect life history refer only to predators and parasitoids when considering natural enemy guilds. It is possible that pathogens have been 
neglected in life history studies because of the technical difficulties involved in assessing host-pathogen relationships within a natural community context. The covert nature of some pathogen infections (Burden et al., 2003; Cooper et al., 2003) has certainly contributed to an underestimate of their importance (Bonsall et al., 2005; Boots et al., 2003). However, modern molecular techniques are now available to enable the balance to be addressed.

\section{Pathogen lifecycles}

Although entomopathogens are taxonomically diverse it is possible to make some generalizations about their life cycles and these are important when considering their importance in host population dynamics (Roy et al., 2006). Viruses, bacteria and protists usually enter the host via oral routes whereas fungi invade through the cuticle (Steinhaus, 1964). Once inside the living host they proliferate and often then kill the insect when resources are depleted, although some pathogens may persist as covert infections inside the host. The final stage of pathogen lifecycles results in the release of infectious propagules for subsequent transmission.

Pathogens and hosts are engaged in a coevolutionary arms race, adapting to maximize their own reproductive output and ultimate fitness. Pathogen fitness is defined as the basic reproductive rate $\left(R_{0}\right)$ - the number of new infections generated by one original infection when invading a clean, susceptible population. Both transmission efficiency and survival within and outside the host are components of $\mathrm{R}_{0}$. The host will be avoiding or resisting the pathogen or optimizing survival after infection. The strategies adopted to achieve this are almost as diverse as the organisms themselves and are modulated by the biotic and abiotic environment in which these organisms coexist and/ or compete for resources (Roy et al., 2006). Some pathogens have wide host ranges with the potential to exploit many different hosts others alternate between biotrophy and saprotrophy and some are host specialists. Entomophthoralean fungi are often extremely host specific, infecting insects within a family, while hypocrealean fungi are more generalist 
in their host range, infecting taxonomically distinct orders of insects and functioning as facultative saprotrophs (Hajek et al., 2008). Baculoviruses are a group of DNA viruses that occur widely, but not exclusively, in Lepidoptera, and have been developed as biopesticides in some instances (Szewczyk et al., 2006). A few baculovirus species appear to be very host specific (e.g. Barber et al 1993) but some such as Mamestra brassicae nucleopolyhedrovirus (MbNPV) and the closely related Panolis flammea nucleopolyhedrovirus (PafINPV) have a relatively wide host range (Doyle et al 1990). Indeed, it is thought that infection of different insect species plays an important role in the maintenance of genetic diversity within virus populations (Hitchman et al., 2007). The bacterium Bacillus thuringiensis as a species has a wide host range but the diversity of crystal proteins (cry toxins) expressed by the bacterium ensures each strain, which carries a different cry toxin, is specific often to an insect order (De Maagd et al., 2001). Pathogen host specificity is a contentious issue and while the taxonomic status of many pathogens remains unresolved (Hibbert et al., 2007) it is difficult to interpret the available literature.

Much of the evidence for host range is laboratory based and such studies do not consider the complexities of a heterogeneous environment (Samways, 2005; Solter, 2006). Potential hosts may be physiologically susceptible under laboratory conditions but this may not translate to ecological susceptibility in the field for a number of reasons (Roy and Pell, 2000; Solter, 2006). For example, under field conditions, hosts may rarely become exposed to concentrations of the pathogen sufficient to cause infection, or there may be a lack of spatial or temporal synchrony between host and pathogen populations. Recent studies have contributed to our understanding of the intricate and often complex nature of insect-pathogen interactions but still much of the emphasis in this research area focuses on entomopathogens as biological control agents. There is a need for fundamental research to further our understanding of the evolution of life history strategies and the ecology of insect-pathogen interactions in the natural environment. 


\section{Economic uses of insect pathogens}

The significance of insect pathogens in regulating economically important insect populations has been recognized and exploited for centuries (Steinhaus, 1956). The successful development of the bacterium $B$. thuringiensis as a control agent of insects marked the advent of modern microbial control (Lacey et al., 2001; Lord, 2005) and the discipline of insect pathology. The link between insect pathology and pest control has continued and a wealth of literature exists on entomopathogens as natural pest-insect population regulators that can be manipulated for enhanced impact in microbial control strategies (Evans, 1986; Lacey et al., 2001; Hajek et al., 2007). Landmark studies that exemplify this include those on gypsy moths, Lymantria dispar, and the fungus Entomophaga maimaga (Reardon and Hajek, 1993); pine beauty moth, Panolis flammea, and nucleopolyhedrosis viruses (Entwistle and Evans, 1987); cotton aphids, Aphis gossypii, and the fungus Neozygites fresenii (Steinkraus et al., 1995); palm rhinoceros beetle, Oryctes rhinoceros, and a non-occluded virus (Bedford, 1980); the bacterium B. thuringiensis and European corn borer, Ostrinia nubilalis (Beegle and Yamamoto, 1992), L. dispar (Burges and Daoust, 1986), vector blackflies and mosquitoes (Lacey and Undeen, 1986) and stored-product pest, Plodia interpunctella (McGaughey, 1986) and the development of genetically modified baculovriuses (Cory 2000, Hails 2001, Hails et al. 2002). These studies on pest insects highlight the potential of entomopathogens to regulate populations, but pathogens are rarely included as natural enemies in studies on non-pest insect species. By definition non-pest insects are often at lower densities than insects designated pest status and this could impede horizontal transmission making highly visible virulent epizootics a rare event.

\section{Effects of pathogens on non-target organisms}

Historically insect pathogens have been noted as potentially important in the regulation of non-pest insects (Perrin, 1976; Dwyer, 1991; Myers, 2000; Lacey et al., 2001) but even the first experimental studies in 1835 focused 
exclusively on economically important insects namely honey bees, silk moths and pest insects (Steinhaus, 1975; Howarth, 2001). This legacy has continued and prevalence of pathogens in non-pest insects is generally considered only when the insects are designated 'non-target' hosts of a generalist entomopathogen that is under development as a microbial control agent. These non-target insects are restricted to particular taxonomic groups such as honey bees, predators, parasitoids or insects closely related to the target pest insect often within ecosystems already perturbed through agriculture or forestry (Hajek et al., 2007; Thomas and Blanford, 2003).

\section{Importance of pathogens in natural systems}

Our understanding of host-pathogen interactions from a pest management perspective, although often limited by scale, does have great relevance when we consider the potential importance of pathogens in populations of non-pest insects of conservation importance in natural and semi-natural ecosystems; for which there is currently very little information. Bierne (1955) comprehensively reviewed the causes of natural fluctuations in abundance of British Lepidoptera and recognized the importance of fungal diseases particularly in wet summers. There are further examples of insect populations cycling from low to high density where pathogens are implicated in declines from high density. For example, epizootics of the fungal pathogen Pandora neoaphidis in nettle aphids, Microlophium carnosum (Perrin, 1976); transmission dynamics of the nucleopolyhedrosis virus of douglas-fir tussock moth, Orgyia pseudotsugata (Dwyer, 1991); population fluctuations of western tent caterpillars, Malacosoma californicum pluviale, attributed to nucleopolyhedrosis virus (Myers, 2000). In a more recent study Graham et al. (2004) assessed the prevalence of a nucleopolyhedrovirus in spatially separated populations of the winter moth Operophtera brumata in Orkney. Virus was found in 11 of the 13 winter moth populations sampled. In two of these winter moth populations more than 50 percent mortality was attributed to viral infection. Furthermore, three previously undescribed reoviruses were found, with prevalence ranging from $0-50 \%$ and presence correlating with 
reduced host fecundity (Graham et al 2006). The authors concluded that the high prevalence of disease, and particularly covert disease, in these natural lepidopteran host populations should encourage further studies into the role of pathogens in the regulation of host insect populations. We agree with this view but further suggest careful consideration should be given to rare species and common species that, with environmental change (such as habitat fragmentation and climate change), are suffering continuing population declines.

\section{Effects of pathogens on rare species}

Most organisms are host to specialist and generalist microbial natural enemies but it is important to ascertain whether these diseases are of conservation concern for our rare species (Lafferty and Gerber, 2002). The transmission of an infectious disease agent through any population will increase with the density of susceptible and infectious hosts (Anderson and May, 1986). However, some species are nationally scarce but locally abundant and transmission between hosts could be facilitated by local aggregations. Simple epidemiological models indicate that there will be densities at which a host population is too low for invasion by a pathogen which relies solely on horizontal transmission, signifying that rare or significantly depleted populations should be at minimal risk from their microbial natural enemies. Horizontal transmission is usually strongly density-dependent and so pathogens are unlikely to result in host extinction, particularly if hosts are rare. Indeed highly pathogenic organisms that rapidly kill their hosts will tend to extinction themselves (burn out) if transmission to new hosts at low densities is insufficient to maintain $R_{0}$ above 1 (Anderson, 1979). Epidemiological theory would therefore suggest that infectious diseases which rely wholly on horizontal transmission are irrelevant to conservation biology when species are rare and subsequently at low population densities for much of the time. This conclusion relies on a number of assumptions which may be contravened. Three examples are given below. 
Until recently it was assumed that the transmission of baculoviruses between hosts was primarily horizontal, resulting in overt and lethal infection. However, there are now several studies which have revealed a degree of vertical transmission of these viruses, with either imperceptible or sublethal effects on host fitness (Hughes et al 1993, 1997, Burden et al 2002, 2003, Graham et al 2004). Furthermore, the evidence suggests that these persistent infections do retain the ability to revert to the overt lethal state (Cooper et al 2003, Burden et al 2006). Theoretical models illustrate that for a wide range of conditions, covert infections may become endemic in the host population, to the exclusion of clean, uninfected hosts (Bonsall et al 2005). Vertical transmission does not rely on host densities being above a critical threshold and therefore persistent, covert infections represent a mechanism by which potentially lethal disease may persist in a declining population. Vertical transmission is also widely reported for bacteria and microsporidia and is potentially an important mechanism for persistence within the life cycle of these groups (Solter, 2006). However, the emphasis for experimental work has been from the perspective of biological control or medical importance and this has limited the range of host orders and pathogens evaluated. This mode of transmission is almost certainly important for far more pathogen species than is currently known.

Our second example challenges our knowledge of the host range of many pathogens. We suggest that many pathogens are thought to be host specific because they have not been looked for beyond the host from which they were originally isolated. In particular, covert infections in 'unexpected' hosts are likely to go undetected. In $O$. brumata populations in which three novel reoviruses were detected, it was subsequently discovered that two other members of the heather feeding community, the Grey Mountain Carpet, Entephria caesiata, and the July highflyer, Hydriomena furcata, were also carriers (Graham 2005, Graham et al 2006). Pathogens with a wider host range can exploit alternative (reservoir) hosts, and once again this decouples the reliance of the pathogen on the density of any one particular host species. 
Thirdly, persistent infective stages may allow pathogens to ride out periods of low host density, theoretically even to the point of causing host extinction. The soil represents a very stable environment which allows some pathogens to persist in an infectious state for many years. Organisms that spend periods of their life-cycle in those environments can be at risk even when they are at low population densities. For example, baculoviruses and fungi (both hypocrealean and entomophthoralean) can persist in the soil where they may infect late stage larvae or pupae of Lepidoptera which descend to the soil to pupate (Roy et al., 2006; Raymond et al., 2005; Meyling and Pell, 2006;).

We conclude, for all the reasons discussed above, that the impact of pathogens, even those thought to be primarily horizontally transmitted, may be greater than has been formally recognized to date.

\section{Effects of environmental change on epidemiology}

Having considered the potential role of pathogens in the natural regulation or even extinction of rare species we now consider how this may be affected directly and indirectly by anthropogenically-induced global environmental change, including climate change and habitat fragmentation, which is becoming increasingly implicated in the decline of populations (Balmford et al, 2005). It is anticipated that infectious diseases in general will increase in prevalence in temperate zones where the climate is predicted to become warmer and wetter (Intergovernmental Panel on Climate Change, 1996; Millenium Ecosystem Assessment, 2005). Infectious diseases and pathogens that have previously had negligible impact on insect populations could have dramatic consequences in the future because of climate change and also habitat destruction.

\section{Effects of climate change}

Even modest changes to the climate are expected to have a rapid impact on the distribution and abundance of pest insects and their associated pathogens 
because they are physiologically sensitive to temperature and have short life cycles, high mobility and high reproductive potential (Ayres and Lombardero, 2000). Many non-pest insects are already responding rapidly to climate change (Parmesan and Yohe, 2003) and expanding northwards (Asher et al., 2001; Hickling et al. 2006). There is currently no information on comparable broad-scale changes in the dynamics of pathogen populations.

It has been recognized for many years that temperature affects biochemical, physiological and behavioural processes in insects and pathogens (Thomas and Blanford, 2003). There are many studies demonstrating temperature optima of insects and pathogens (Carruthers et al., 1992; Kobayashi et al., 1981; Watson et al., 1993). Recent research has shown that temperature can also have a crucial role in mediating the outcome of host-pathogen interactions (Thomas and Blanford, 2003). For example, thermal effects have been demonstrated for insect pathogenic fungi (Caruthers et al., 1992; Watson et al., 1993), viruses (Kobayashi et al., 1981) and microsporidia (Campbell et al., 2007). Temperature can affect host-pathogen dynamics in a variety of ways such as: alterations to the latent period of infection (Blanford and Thomas, 1999), host recovery and pathogen mortality (Roy et al., 2006), pathogen and host replication (Kobayashi et al., 1981), pathogen virulence and host resistance (Blanford and Thomas, 1999; Arthurs and Thomas, 2000; Stacey et al., 2003). Insects (and their pathogens) are likely to track ambient temperature (thermoconforming) and are likely to be more vulnerable to changes in temperature for example as a consequence of global warming. However, effects of environmental temperature change on host-pathogen interactions will be varied because pathogen and host traits will have different thermal optima (Thomas and Blanford, 2003).

It is difficult to predict the ultimate outcome of host-pathogen interactions in response to climate change because of the complexity of the interactions and lack of available data. It is common for the performance of insect pathogens used as biological control agents in the field to be highly erratic (Blanford and 
Thomas, 1999; Thomas and Blandford, 2003). This variability is also evident in natural systems whereby in some years a pathogen can reach epizootic proportions and in other years hosts remain uninfected. Temperature can affect both host susceptibility and (or) pathogen virulence (where virulence is defined as the net effect of the host-pathogen interaction on host fitness) and consequently influence disease dynamics, however, responses can vary from positive or negative linear responses to more complex relationships (Blanford and Thomas, 1999; Blanford and Thomas, 2000;Thomas and Blanford, 2003). For example, the entomophthoralean fungus Entomophaga grylli can be a major mortality factor of the variegated grasshopper Zonocerus variegatus (Chapman and Page, 1979). However, an increase in environmental temperature of $2{ }^{\circ} \mathrm{C}$ enables infected individuals to recover from the pathogen by raising body temperature through behaviour such as basking (Blanford et al., 2000). In contrast, insect viruses generally exhibit low virulence at cool temperatures and increase in virulence with increasing in temperature eventually reaching an asymptote as temperature rises further (Johnson et al., 1982). Not all insects are behavioural thermoregulators but it should not be assumed that thermoconforming insects lack thermal sensitivity; environmentally driven variation in host body temperature will also influence host defence mechanisms such as the innate immune system, host density and melanin production (Thomas and Blanford, 2003; Stacey et al., 2003).

Several Entomophthoralean fungi exhibit an adaptive diurnal pattern of host death (Neilson and Hajek, 2006; Roy et al., 2006); host death occurs in the late afternoon or early evening and the fungus releases infective conidia during the night when relative humidity is high. This diurnal pattern benefits transmission of the fungus between hosts. The precision of synchrony, of host death with environmental conditions favouring fungal transmission, is associated with the climatic region in which the pathogen evolved (Milner et al., 1984). So fungal species with a precise timing of death and a short sporulation time appear to be adapted to continental weather conditions with cycles of dry and moist conditions during the day and night (Milner et al., 
1984). In contrast, fungal species displaying weak diurnal rhythm in mortality with prolonged periods of sporulation seem adapted to cool, moist climates with less diurnal fluctuation in temperature and humidity (Milner et al., 1984). The Entomophthoralean fungus Entomophaga maimaiga infects Lymantria dispar (gypsy moth) larvae and sporulation is synchronised with a diurnal rhythm (Neilson and Hajek, 2006). An empirical study on this host-pathogen system demonstrated that by raising the temperature from 15 to $20^{\circ} \mathrm{C}$ the peak death time narrowed and sporulation was initiated earlier at night. Furthermore, alterations to abiotic conditions will differentially influence pathogen (and host) species of different genotypes. For example, Bidochka et al. (2002) demonstrated that the habitat from which the isolate was derived drives the population structure of the fungus $B$. bassiana. Isolates (genotypes) of the fungal species $B$. bassiana from artic and forested habitats grew at lower temperatures than those isolates from agricultural habitats which grew at temperatures in excess of $37^{\circ} \mathrm{C}$ (Bidochka et al., 2002).

In summary, the life history traits of insect hosts and their pathogens are strongly influenced by temperature (and other abiotic conditions) and the precise outcome of an interaction will depend on the relevant environmental range of the genotypes of host and pathogen and the prevailing conditions. Spatial and temporal variation in host-pathogen dynamics is commonly observed and a minimal change in temperature could alter the outcome of the interaction dramatically. There is considerable need for more studies

examining insect host-pathogen systems under a range of constant and fluctuating temperatures.

\section{Effects of habitat destruction}

Theories on the dynamics of pathogens in fragmented habitats have been based on the metapopulation paradigm whereby, as patches become smaller and more separated, rates of extinction increase and rates of recolonisation decrease (Hanski, 1997). It is also assumed that the remaining habitat is 
likely to be degraded as a consequence of high demand on the reduced resources and, therefore, individuals residing in these habitats could be abnormally stressed resulting in increased susceptibility to disease (Lafferty and Gerber, 2002). Reduced population size would increase the incidence of inbreeding which could promote a long-term loss in genetic diversity and hence reduced potential to adapt to infectious diseases (Lyles and Dobson, 1993). The risk of microbial control agents spreading from the site of application into environmentally sensitive areas will be increased in fragmented habitats because of greater edge effects (Lafferty and Gerber, 2002). It appears that environmental change has the potential to affect epidemiology but these predictions need to be tested experimentally, on insect-pathogen systems, to gain an accurate measure of the overall impact. Currently such studies are lacking.

The spatial dynamics of pathogens have been extensively studied (Ostfeld et al., 2005) but not at the landscape level. Mechanisms of pathogen dispersal from an infected to an uninfected host are extremely varied ranging from direct contact (sexual diseases) and near-direct contact (pathogens released and then inhaled or ingested) to indirect contact via a vector (Ostfeld et al., 2005). In all cases the probability of pathogen transmission decreases with increasing distance between susceptible hosts (except in the case of vertical transmission, when hosts may carry the seeds of their own destruction). So factors influencing the spatial distribution of pathogens, host and vectors are fundamental to disease dynamics. Work on viruses has highlighted the importance of spatial structure on pathogen survival and transmission. Habitat can influence the persistence of pathogens in the field; baculovirus in forested (sitka spruce and oak) areas retained infectivity longer than in an unshaded (heather) habitat (Raymond et al., 2005). The spatial scale of most host-pathogen studies is often at the field level or less. Few empirical studies incorporate a landscape approach (Barta and Cagan, 2003). Consideration of the heterogeneous nature of the environment, embracing the challenges of 
the landscape scale, in which pathogens and hosts coexist will be important in understanding how these systems will respond as the environment changes.

Corridors connecting remnant habitat patches are regarded as a conservation strategy (McCallum and Dobson, 2002). However, Hess (1996) developed a model, based on the classical Levins (1969) metapopulation structure, for pathogens in fragmented habitats which led to the conclusion that movement of individuals among populations is risky. However, McCallum and Dobson (2002) challenged this conclusion, recognizing that not all pathogens are host specific and that a second host species may act as a pathogen reservoir. They extended the simplified model by Hess (1996) to examine cases where the pathogen infects both a rare host and a common reservoir species (McCallum and Dobson, 2002). From this revised model it was concluded that habitat loss will cause extinction of the pathogen before loss of the host and, furthermore, while the pathogen may spread through corridors between habitat patches, the benefit of permitting recolonisation of vacant patches by the host counterbalances the cost of disease spread (McCallum and Dobson, 2002). In both the Hess and the McCallum and Dobson models, the pathogens were directly transmitted between hosts. Many entomopathogens are indirectly transmitted, but do form persistent reservoirs external to the host as well as in alternative host species. Consequently the latter model is the most applicable, and increasing connectance between habitat fragments is likely to be beneficial for rare species.

The spatial complexity of population structure is an inherent component of source-sink metapopulation and metacommunity models (Hanski and Gilpin, 1991; Hanski and Simberloff, 1997; Namba et al., 1999; Rodriguez and Torres-Sorando, 2001). These models have demonstrated that habitat partitioning can promote coexistence of prey by relaxing apparent competition mediated by a shared predator (Holt, 1984) but could also result in extinction of the predator species (if prey productivity in a source population is insufficient to "rescue" a deficient sink population) or the prey species (if the 
source is too rich giving rise to shared predation) (Namba et al., 1999). The number of sinks and spatial arrangement and connectivity between patches differentially influence persistence of populations in different trophic levels (Namba et al., 1999). The probability of establishment of a pathogen within a host patch is predicted to decrease with increasing spatial partitioning (fragmentation) and with decreasing host movement between patches (Rodriguez and Torres-Sorando, 2001). These models examine the role of trophic and spatial complexity on population persistence but there is little empirical evidence to support the model predictions. We believe that pathogens and their hosts could be exemplary systems for empirically testing theoretical models based on metacommunity structure.

In a recent empirical study Tscharntke et al. (2002) examined the interactions between insects (grassland butterflies, legume and rape feeding herbivores and their parasitoids) in a fragmented landscape. Habitat fragmentation differentially affected the interactions between species with varying community structure. Habitat fragmentation was more detrimental to specialised butterflies than less specialized oligophagous and polyphagous herbivores (Tscharntke et al., 2002). Species richness and abundance of polyphagous butterfly species was higher in small rather than large calcareous fragments and illustrates the importance of the landscape matrix within which the patches are embedded for less specialized species. Therefore, Tscharntke et al. (2002) conclude that an intermediate fragmentation conservation strategy (combining the advantages of both several small and single large fragment structures) could be beneficial in a human-dominated landscape. Further empirical studies are urgently needed to underpin the theoretical developments in this area. Briggs et al. (1995) stated that the extent to which pathogen dynamics will drive, rather than be driven by, the dynamics of their host is an important and open question in many natural systems. This is still a fundamental question today and understanding the role of pathogens in regulating host populations in fragmented habitats appears particularly challenging. 


\section{Future perspectives}

Conservation biology and the development of practical approaches to the prevention of species declines and extinctions are dependent on the integration of theories and disciplines. There is no doubt that in most studies on insect conservation the roles of insect pathogens largely go unnoticed. Pathogens may not drive a host to extinction but they may result in population depletion to such a low density that other factors become important such as Alee effects or random stochastic events (Lafferty and Gerber, 2002). As discussed some species are nationally scarce but locally abundant and transmission between hosts could be facilitated by local aggregations. Further research on spatial epidemiology of insect pathogens is required if we are to make realistic predictions of the impact of environmental change on host-pathogen dynamics.

There is currently much debate regarding the influence that a single mortality agent such as a pathogen can have on host regulation (Graham et al., 2004). Host-pathogen relationships are complex and can be extremely subtle often varying both spatially and temporally; pathogen density within a host population is often underestimated because the pathogen remains undetected in symptomless individuals (Graham et al., 2004) or studies are not of sufficient spatial or temporal scale to capture the role of pathogens on life history traits.

We urgently need to apply, more widely, the wealth of molecular techniques available to document the diversity and prevalence of pathogens, in all their guises, within non-pest insect populations. Only then can we confidently comment on the current role of insect pathogens in population regulation and on the impact of future environmental regimes on host-pathogen interactions. Insect pathology has never been more relevant than in the current period of rapid environmental change. 


\section{Acknowledgements:}

$\mathrm{HER}, \mathrm{HH}$, RSH were funded by the Environmental Change Integrating Fund through the NERC Centre for Ecology and Hydrology. JKP was funded by the Department for Environment, Food and Rural Affairs of the UK (Defra). Rothamsted Research receives grant-aided support from the Biotechnology and Biological Sciences Research Council of the UK (BBSRC).

\section{References:}

Anderson, R.M. 1979. Parasite pathogenicity and the depression of host population equilibria. -Nature 279: 150-152.

Anderson, R.M. and May, R.M. 1986. The invasion, persistence and spread of infectious diseases within animal and plant communities. - Philosophical Transactions of the Royal society of London, Series B 314: 533-570.

Arthurs, S. And Thomas, M.B. 2000. Effects of a mycoinsecticide on feeding and fecundity of the brown locust, Locustana pardalina. - Biocontrol Science and Technology 10: 321-329.

Asher, J., Warren, M., Fox, R., Harding, P., Jeffcoate, G. And Jeffcoate, S. 2001. The millennium atlas of butterflies in Britain and Ireland. Oxford University Press, UK

Ayres, M.P. and Lombardero, M.J. 2000. Assessing the consequences of global change for forest disturbance from herbivores and pathogens. - The Science of the Total Environment 262: 263-286.

Balmford, A., L. Bennun, B. ten Brink, D. Cooper, I.M. Côté, P. Crane, A. Dobson, N. Dudley, I. Dutton, R.E. Green, R. Gregory, J. Harrison, E.T. Kennedy, C. Kremen, N. Leader-Williams, T. Lovejoy, G. Mace, R. May, P. Mayaux, J. Phillips, K. Redford, T.H. Ricketts, J.P. Rodriguez, M. Sanjayan, P. 
Schei, A. van Jaarsveld, \& B. A. Walther. 2005. Science and the Convention on Biological Diversity's 2010 target. - Science 307: 212-213.

Barber, K.N., Kaupp, W.J. and Holmes, S.B. (1993). Spexificity testing of the nuclear polyhedrosis virus of the gypsy moth Lymantria dispar (L.) (Lepidoptera: Lymantriidae). - Canadian Entomologist 125: 1055-66.

Barta, M. \& Cagán, L. 2003. Entomophthoralean fungi associated with common nettle aphid (Microlophium carnosum Buckton) and the potential role of nettle patches as reservoirs for the pathogens in landscape. - Anzeiger für Schädlingskunde 76: 6-13.

Bedford, G.O. 1980. Biology, ecology and control of palm rhinoceros beetles. - Annual Review of Entomology 25: 309-339.

Beegle, C.C. and Yamamoto, T. 1992. History of Bacillus thuringiensis Berliner research and development. - Canadian Entomologist 124: 587-616.

Bidochka, M.J., Menzies, F.V. and Kamp, A.M. 2002. Genetic groups of the insect-pathogenic fungus Beauveria bassiana are associated with habitat and thermal growth preferences. - Archives of Microbiology 6: 531-537.

Bierne, B.P. 1955. Natural fluctuations in abundance of British Lepidoptera. Entomologists Gazette 6: 21-52.

Blanford, S. and Thomas, M.B. 1999. Host thermal biology: the key to understanding insect-pathogen interactions and microbial pest control? Agricultural and Forest Entomology 1: 195-202.

Blanford, S., Thomas, M.B., Pugh, C. and Pell, J.K. (2003) Temperature checks the Red Queen? Resistance and virulence in a variable environment. Ecology Letters 6: 2-5 
Bonsall, M.B. Sait, S.M. and Hails, R.S. 2005. Invasion and dynamics of covert infection strategies in structured populations. - Journal of Animal Ecology 74: 464-474.

Boots, M., Greenman, J., Ross, D., Norman, R., Hails, R. and Sait, S. 2003. The population dynamical implications of covert infections in hostmicroparasite interactions. - Journal of Animal Ecology 72: 1064-1072.

Briggs, C.J., Hails, R.S., Barlow, N.D. and Godfray, H.C.J. (1995) The dynamics of insect-pathogen interactions. In: Ecology of infectious diseases in natural populations (ed.: Grenfell, B.T. and Dobson, A.P.). Cambridge University Press.

Burden, J.P., Griffiths, C.M., Cory, J.S., Smith, P. and Sait, S.M. (2002). Vertical transmission of a sublethal granulovirus infection in the Indian meal moth Plodia interpunctella. - Molecular Ecology 11: 547-55.

Burden, J.P., Nixon, C.P., Hodgkinson, A.E., Possee, R.D., Sait, S.M., King, L.A. and Hails, R.S. (2003) Covert infections as a mechanism for long-term persistence of baculoviruses. - Ecology Letters 6: 524-531.

Burden, J.P., Possee, R.D., Sait, S.M., King, L.A. and Hails, R.S. (2006). Phenotypic and genotypic characterisation of persistent baculovirus infections in populations of the cabbage moth (Mamestra brassicae) within the British Isles. - Archives of Virology 151(4): 635-649.

Burges, H.D. and Daoust, R.A. 1986. Current status of the use of bacteria as biocontrol agents. In: Samson, R.A., Vlak, J.M. Peters, D. (eds) Fundamental and Applied Aspects of Invertebrate pathology. Foundation of the Fourth 
International Colloquium of Invertebrate pathology. Wageningen, The Netherlands, 514-517.

Carruthers, R.I., Larkin, T.S. and Firstencel, H. 1992. Influence of thermal ecology on the mycosis of a rangeland grasshopper. - Ecology, 73, 190-204.

Cooper, D., Cory, J.S., Theilmann, D.A. and Myers, J.H. (2003). Nucleopolyhedroviruses of forest and western tent caterpillars: crossinfectivity and evidence for activation of latent virus in high density field populations. - Ecological Entomology 28: 41-50.

Cory, J.S. (2000). Assessing the risks of releasing genetically modified virus insecticides: progress to date. - Crop protection 19: 779-785.

De Maagd, R.A., Bravo, A. and Crickmore, N. 2001. How Bacillus thuringiensis has evolved specific toxins to colonise the insect world. - Trend in Genetics 17: 193-199.

Doyle, C.J., Hirst, M.L., Cory, J.S. and Entwistle, P.F. (1990). Risk assessment studies: detailed host range testing of the wild-type cabbage moth Mamestra brassicae Lepidoptera Noctuidae nuclear polyhedrosis virus. - Appl. Environ. Micro. 56: 2704-10.

Dwyer, G. 1991. The roles of density, stage and patchiness in the transmission of an insect virus. - Ecology 72: 559-574.

Entwistle, P.F. and Evans, H.F. 1987. Trials on the control of Panolis flammea with a nuclear polyhedrosis virus. In: S.R. Leather, J.T. Stoakley and H.F. Evans, Editors, Population Biology and Control of the Pine Beauty Moth, Forestry Commission Bulletin 67, HMSO, UK (1987), pp. 61-68. 
Evans, , H.F. 1986. Ecology and epizootiology of Baculoviruses. - In: Granados, R.R. and Federici, B.A. (eds), The Biology of Baculoviruses. CRC Press, Boca, Raton, Florida, pp. 89-132.

Graham, R.I. (2005). The impact of viral pathogens on host Lepidoptera populations: the Winter moth and its natural enemies. PhD thesis, Oxford Brookes University.

Graham, R.I., Tyne, W.I., Possee, R.D., Sait, S.M. and Hails, R.S. 2004. Genetically variable nucleopolyhedrovirus isolated from spatially separate populations of the winter moth Operophtera brumata (Lepidoptera: Geomedtridae) in Orkney. - Journal of Invertebrate pathology 87: 29-38.

Graham, R.I., Rao, S., Possee, R.D., Sait, S.M., Mertens, P.C. and Hails, R.S. (2006). Detection and characterisation of three novel species of reovirus (Reoviridae), isolated from geographically separate populations of the winter moth Operophtera brumata (Lepidoptera: Geometridae) on Orkney. - Journal of Invertebrate Pathology, 91, 79-87.

Hails, R.S. (2001). Natural and Genetically Modified baculoviruses: environmentally friendly pest control or an ecological threat? - Outlook on Agriculture 30 (3): 171-178.

Hails, R.S., Hernandez-Crespo, P., Sait, S.M., Donnelly, C.A., Green, B.M. and Cory, J.S. (2002). Transmission patterns of natural and recombinant baculoviruses. - Ecology, 83, 906-916.

Hajek, A. 2004. Natural enemies: an introduction to biological control. Cambridge University Press, Cambridge. 
Hajek, A., McManus, M. L. and Delalibera, I. 2008. A review of introductions of pathogens and nematodes for classical biological control of insects and mites. - Biological Control (In press)

Hanski, I.A. and Gilpin, M.E. 1991. Metapopulation dynamics: Brief history and conceptual domain. Biological Journal of the Linnean Society 42: 3-16.

Hanski, I.A. and Simberloff, D. 1997. The metapopulation approach, its history, conceptual domain, and application in conservation. In Metapopulation biology: ecology, genetics and evolution (ed. I. Hanski and M.E.Gilpin), pp. 5-26. London: Academic.

Hanski, I. 1997 Metapopulation dynamics: from concepts and observations to predictive models. In Metapopulation biology: ecology, genetics and evolution (ed. I. Hanski and M.E.Gilpin), pp. 69-91. London: Academic.

Hess, G. 1996. Disease in metapopulation models: implications for conservation. - Ecology 77: 1671-1632.

Hibbett D.S., Binder M., Bischoff J.F., Blackwell M., Cannon P.F., Eriksson O.E., Huhndorf S., James T., Kirk P.M., Lücking R., Thorsten Lumbsch H., Lutzoni F., Brandon Matheny P., McLaughlin D.J., Powell M.J., Redhead S., Schoch C.L., Spatafora J.W., Stalpers J.A., Vilgalys R., Aime M.C., Aptroot A., Bauer R., Begerow D., Benny G.L., Castlebury L.A., Crous P.W., Dai Y.C. , Gams W., Geiser D.M., Griffith G.W., Gueidan C., Hawksworth D.L., Hestmark G., Hosaka K., Humber R.A., Hyde K.D., Ironside J.E., Kõljalg U., Kurtzman C.P., Larsson K.-H., Lichtwardt R., Longcore J., Miądlikowska J., Miller A., Moncalvo J.M., Mozley-Standridge S., Oberwinkler F., Parmasto E., Reeb V., Rogers J.D., Roux C., Ryvarden L., Sampaio J.P., Schüßler A., Sugiyama J., Thorn R.G., Tibell L., Untereiner W.A., Walker C., Wang Z., Weir A., Weiss M., White M.M., Winka K., Yao Y.J. \& Zhang N. 2007: A higher-level phylogenetic classification of the Fungi. - Mycol. Res. 111: 509-547. 
Hickling, R., Roy, D.B., Hill, J.K., Fox, R., and Thomas, C.D. 2006. The distributions of a wide range of taxonomic groups are expanding polewards. Global Change Biology 12: 450-455.

Hitchman, R.B., Hodgson, D.J., King, L.A., Hails, R.S., Cory, J.S. and Possee, R.D. 2007. Host mediated selection of pathogen genotypes as a mechanism for the maintenance of baculovirus diversity in the field. - Journal of Invertebrate Pathology 94: 153-162.

Holt, R.D. 1984. Spatial heterogeneity, indirect interactions, and coexistence of prey species. - American Naturalist 124: 377-406.

Howarth, F.G. 2001 Environmental issues concerning the importation of nonindigenous biological control agents. - In: Lockwood, J A, Howarth, F G and Purcell, M F (eds), Balancing nature: assessing the impact of importing nonnative biological control agents (an international perspective). Entomological Society of America, pp.70-99.

Hughes, D., Possee, R.D. and King, L.A. (1993). Activation and detection of a latent baculovirus resembling Mamestra brassicae nuclear polyhedrosis virus in M. brassicae insects. - Virology 194: 600 - 15.

Hughes, D.S., Possee, R.D. and King, L.A. 1997. Evidence for the presence of a low level, persistent baculovirus infection of Mamestra brassicae insects. Journal of General Virology 78: $1801-1805$.

Intergovernmental Panel on Climate Change, 1996. Intergovernmental Panel on Climate Change. World Meteorological Organization (WMO) and the United Nations Environment Programme (UNEP). 
Johnson, D.W., Boucias, D.G., Barfield, C.S. and Allen, G.E. 1982. A temperature -dependent development model for a nucleopolyhedrosis virus of the velvetbean caterpillar Anticarsia gemmatalis (Lepidoptera: Noctuidae). - Journal of Invertebrate Pathology 40: 292-298.

Kobayashi, M., Inagaki, S. and Kawase, S. 1981. Effects of high temperature on the development of nuclear polyhedrosis virus in the silkworm Bombyx mori. - Journal of Invertebrate Pathology 38:386-394.

Lacey, L.A. and Undeen, A.H. 1986. Microbial control of blackflies and mosquitoes. - Annual Review of Entomology 31: 265-296.

Lacey, L.A., Frutos, R. Kaya, H.K. and Vail, P. 2001. Insect pathogens as biological control agents: do they have a future? - Biological control 21: 230248.

Lafferty, K.D. and Gerber, L.R. 2002. Good medicine for conservation biology: the intersection of epidemiology and conservation theory. Conservation Biology 16: 593-604.

Levins, R. 1969. Some demographic and genetic consequences of environmental heterogeneity for biological control. Bull. Entomol. Soc. Am. 15: $237-240$

Lord, J.C. 2005. From Metchnikoff to Monsanto and beyond: The path of microbial control. - Journal of Invertebrate Pathology 89: 19-29.

Lyles, A. M. and Dobson, A. P. 1993. Infectious disease and intensive management: population dynamics, threatened hosts, and their parasites. Journal of Zoo and Wildlife Medicine 24: 315. 
McCallum, H. and Dobson, A. 2002. Disease, habitat fragmentation and conservation. - Proc. R. Soc. Lond. B 269: 2041-2049.

McGaughey, W.H. 1986. Insect resistance to the biological insecticide Bacillus thuringiensis. - Science 229: 193-195.

Millenium Ecosystem Assessment. 2005. Ecosystems and Human Well-Being: Biodiversity Synthesis. World Resources Institute, Washington, DC.

Milner RJ, Holdom DG \& Glare TR (1984) Diurnal patterns of mortality in aphids infected by entomophthoralean fungi. - Entomologia Experimentalis et Applicata 36: 37-42.

Myers, J.H. 2000. Population fluctuations of the western tent caterpillar in southwestern British Columbia. - Population Ecology 42: 231-241.

Meyling, N.V. \& Pell, J.K. 2006. Detection and avoidance of an entomopathogenic fungus by a generalist insect predator. - Ecological Entomology 31: 162-171.

Namba, T., Umemoto, A. and Minami, E. 1999. The effects of habitat fragmentation on persistence of source-sink metapopulations in systems with predators and prey or apparent competitors. - Theoretical Population Biology 56: 123-137.

Nielson, C. and Hajek, A.E. 2006. Diurnal pattern of death and sporulation in Entomophaga maimaiga -infected Lymantria dispar. - Entomologia Experimentalis et Applicata 118: 237-243

Ostfeld, R.S., Glass, G.E. and Keesing, F. 2005. Spatial epidemiology: an emerging (orre-emerging) discipline. - Trend in Ecology and Evolution 20: 328-336. 
Parmesan, C. \& Yohe, G. 2003. A globally coherent fingerprint of climate change impacts across natural systems. - Nature 421: 37-42.

Perrin, R.M. 1976 The population dynamics of the stinging nettle aphid, Microlophium carnosum (Bukt.). - Ecological Entomology 1: 31-40.

Raymond, B., Hartley, S.E., Cory, J.S. and Hails, R.S. 2005. The role of food plant and pathogen-induced behaviour in the persistence of a nucleopolyhedrovirus. Journal of Invertebrate Pathology 88: 49-57.

Reardon, R. and Hajek, A. 1993. Entomophaga in North America: a review. Integrated Pest Management Publication, USDA Forest Service.

Rodriguez, D.J. and Torres-Sorando, L. (2001) Models of infectious diseases in spatially heterogeneous environments. - Bulletin of Mathematical Biology 63: 547-571.

Roy, H.E. and Pell, J.K. 2000. Interactions between entomopathogenic fungi and other natural enemies: implications for biological control. -Biocontrol Science and Technology 10: 737-752.

Roy, H.E. and Cottrell, T.E. (2008) Forgotten natural enemies:interactions between coccinellids and insect-parasitic fungi. European Journal of Entomology 105: 391-398.

Roy, H.E., Steinkraus, D., Eilenberg, E., Pell, J.K. and Hajek, A. 2006. Bizarre Interactions and Endgames: Entomopathogenic Fungi and their Arthropod Hosts. - Annual Review of Entomology 51: 331-357.

Samways, M.J. 2005 Insect diversity conservation. Cambridge University Press, Cambridge. 
Solter, L.F. 2006. Transmission as a predictor of ecological host specificity with a focus on vertical transmission of microsporidia. - Journal of Invertebrate Pathology 92: 132-140.

Stacey, D.A., Thomas, M.B., Blanford, S., Pell, J.K., Pugh, C. and Fellowes, M.D.E. (2003) Genotype and temperature influence pea aphid resistance to a fungal entomopathogen. - Physiological Entomology 28: 75-81

Steinhaus, E.A. 1956. Microbial control: the emergence of an idea. - Hilgardia 26: $107-160$.

Steinhaus, E.A. 1964. Microbial diseases of insects. - In: Debach, P. (ed) Biological control of insect pests and weeds. Chapman and Hall, London, pp. 515-547.

Steinhaus, E.A. 1975. Disease in a minor chord, Ohio State University Press, Columbus.

Steinkraus, D.C., Hollingsworth, R.G. and slaymaker, P.H. 1995. Prevalence of Neozygites fresenii (Entomophthorales: Neozygitaceae) on cotton aphids (Homoptera: Aphididae) in Arkansas cotton. - Environmental Entomology 24: 465-474.

Szewczyk, B., Hoyos-Carvajal, L., Paluszek, M., Skrzecz, I. and Lobo de Souza, M. 2006. Baculoviruses - re-emerging biopesticides. - Biotechnology Advances 24: 143-160.

Thomas, M.B. and Blanford, S. 2003. Thermal biology in insect-parsite interactions. - Trends in Ecology and Evolution 18: 344-350. 
Tscharntke, T., Steffan-Dewenter, I., Kreuss, A. and Thies, C. 2002. Contribution of small habitat fragments to conservation of insect communities of grassland-cropland landscapes. - Ecological Applications 12: 345-363

Watson, D.W., Mullens, B.A. and Petersen, J.J. 1993. Behavioural fever response of Musca domestica ( Diptera: Muscidae) to infection by Entomophthora muscae. - Journal of Invertebrate Pathology, 61, 10-16.

Watson, R.T., Heywood, V.H., Baste, I., Dias, B., Gamez, R., Janetos, T., Reid, W. and Ruark, R. 1995. Global Biodiversity Assessment. Cambridge University Press, Cambridge. 